\title{
Developmental Expression of Vasopressin in the Human Hypothalamus: Double-Labeling with In Situ Hybridization and Immunocytochemistry
}

\author{
KEIKO MURAYAMA,' RICK B. MEEKER, SHIGEO MURAYAMA, AND \\ ROBERT S. GREENWOOD \\ Departments of Neurology /K.M., R.B.M., R.S.G.J, Pathology [S.M.J, and Pediatrics [R.S.G.] and the Curriculum \\ in Neurobiolog. /R.B.M.. R.S.G.J. University of North Carolina School of Medicine, Chapel Hill, North Carolina \\ 27599
}

\begin{abstract}
The developmental expression of arginine vasopressin (VP) and VP mRNA in human hypothalamus was studied using combined immunocytochemistry (ICC) for VP-neurophysin II and in situ hybridization (ISH) for VP mRNA. Routine formalin-fixed autopsy material was used from 22 cases ranging in age from 18 wk of gestation to $21 \mathrm{yr}$. VP-neurophysin II immunoreactive cells were detected in the supraoptic, accessory supraoptic, and paraventricular nuclei of all brains examined. The average size of the immunocytochemically labeled cells increased until birth and remained constant thereafter. VP mRNA was first detected in cells at 21 wk gestation; 3 wk after the first detectable VP by ICC. After 27 wk of gestation, consistent and strong signals were obtained from the specimens that were double-labeled for both immunoreactive VP-neurophysin II and VP mRNA. Three populations of double-labeled cells were identified: type 1 , intensely positive for both ISH and ICC (most magnocellular neurons); type 2, positive for ISH and weak or negative for ICC (rare and generally found in younger fetuses), and type 3 , positive for ICC and weak or negative for ISH (mostly scattered in accessory nuclei). Thus, double-labeling techniques can be routinely used on frozen or paraffin sections of human autopsy material for the simultaneous assessment of both message and peptide. In the human fetus, the relatively late appearance of adult-like levels of VP mRNA in the magnocellular neuroendocrine cells suggests an association with the development of functional synaptic interactions in this system. (Pediatr Res 33: 152-158, 1993)
\end{abstract}

\section{Abbreviations}

E, embryonic day

ICC, immunocytochemistry

ISH, in situ hybridization histochemistry

NP, neurophysin

SON, supraoptic nucleus

PVN, paraventricular nucleus

PN, postnatal day

SON-acc, accessory SON

VP, vasopressin, arginine-vasopressin

WG, week(s) of gestation

SSC, standard saline citrate

Received January 16, 1992; accepted September 28, 1992.

Correspondence and reprint requests: Dr. Robert Greenwood, Department of Neurology. CB 7025.751 Burnett Womack Building. University of North Carolina, Chapel Hill NC 27599-7025.

Now at the Department of Pediatrics. National Rehabilitation Center for Handicapped Children. 1-1-10. Komone. Itabashi-ku. Tokyo. 173, Japan.
The control of human neuropeptide gene expression during development is poorly understood. Many of the neuropeptide genes including the VP gene have been cloned and have been used extensively for ISH studies in animals. With slight modifications, these techniques can be adapted for use in human autopsy tissue for the examination of gene expression associated with development of physiologic function (1), or disease processes. ISH combined with ICC allows the simultaneous assessment of both message content and the level of peptide expression that can be correlated with fundamental stages of neuroendocrine cell development such as 1 ) the development of the necessary subcellular organelles for mRNA and peptide synthesis, 2) the development of neurosecretory terminal endings that secrete the peptide, and 3) innervation of the cell by regulatory neurons for synaptic control of VP cell activity.

Previous developmental studies in mice and rats utilizing ICC and RIA have indicated that VP can be detected soon after migration is complete (E13.5-16) but is more plentiful by E17$18(2-5)$. The earliest detectable VP may represent precursor forms of the peptide, because the fully processed form of the peptide is not present until E16 (6). ISH studies have detected VP mRNA as early as E16 (7). The ability of the cell to produce VP precedes the development of neurosecretory terminals in the neural lobe of the pituitary, which in rats begins at approximately E18 $(2,4,6)$ and progresses to near-adult levels by PN30 $(4,6)$. Although VP mRNA is a necessary precursor for VP peptide synthesis, the above experiments and our recent experiments on adult rats (8) suggest that many neurons may not express significant amounts of message until an appropriate stimulus triggers secretion of peptide by the cells. By analogy, it might be expected that VP mRNA expression is low during development until the neurosecretory terminals are formed and release capability is established.

The limited data available for humans suggest that the VP neuroendocrine system appears very early in development. Neurophysin and VP immunoreactivity are first seen during the 11 th WG (9). Neuron number stabilizes by the 16th WG, and peptide content continues to increase rapidly through the 2 nd trimester (10) until birth (9). Once VP content reaches maturity, it remains stable throughout life (11). The developmental expression of VP mRNA in human hypothalamus has not yet been examined.

To establish the double-labeling technique and to explore the development of VP cells in the human, we have combined ICC for VP peptide and ISH for VP mRNA for the analysis of human autopsy material ranging from $18 \mathrm{WG}$ to $21 \mathrm{y}$ of age. Both the peptide and the mRNA were readily detected in formalin-fixed, paraffin-embedded material from autopsy files as well as formalin-fixed frozen sections. A previous study has found that VP mRNA is readily and reliably detectable and quantifiable in the human postmortem brain (1). Our studies establish combined 
ISH and ICC as a reliable method for the evaluation of human hypothalamus and demonstrate the early development of the VP neuroendocrine system in humans.

\section{MATERIALS AND METHODS}

Tissue source. Twenty-two human hypothalami obtained at routine brain cutting from 1989 to 1991 served as the sources of tissue for the present work. None of the cases had any clinical history of neurologic or neuroendocrinologic abnormalities. No attempt was made to document premorbid hydration status. Brains were fixed in $10 \%$ buffered formalin from 8 to $20 \mathrm{~d}$. Brains of preterm fetuses were fixed in the skull with dura open. Table 1 summarizes the ages, sex, postmortem time in hours, and the cause of death for each case in the present analysis. A coronal slice beginning at the optic chiasm and extending $5 \mathrm{~mm}$ posterior was obtained at brain cutting, and the area of the hypothalamus was dissected free and cut in half in the sagittal plane through the third ventricle. The left hypothalamus was embedded in paraffin, and $8-\mu \mathrm{m}$-thick sections were obtained. The initial sections were stained with hematoxylin and eosin, Nissl's stain, and Fuxe myelin stain for neuropathologic evaluation. In some cases, serial sections were obtained from an entire block for detailed anatomical evaluation. The right hypothalamus was frozen in isopentane chilled by liquid nitrogen, and 20$\mu \mathrm{m}$ serial sections were cut in a cryostat (Reichert Jung, Leica Inc., Deerfield, IL). Paraffin blocks of the hypothalamus from autopsy files were also examined. Various areas of the CNS were also examined for neuropathologic evaluation.

The nomenclature used for the magnocellular hypothalamic nuclei was that used by Morton (12): SON, PVN, and SON-acc.

Materials. The rabbit anti-VP-NP II polyclonal antibody was

Table 1. Summary of age, sex, postmortem interval, and cause of death for the 22 cases used in present study

\begin{tabular}{|c|c|c|c|c|}
\hline Case & $\begin{array}{l}\text { Age } \\
(y)^{*}\end{array}$ & Sex & $\begin{array}{c}\text { Postmortem } \\
\text { interval (h) }\end{array}$ & Diagnosis \\
\hline 1 & $0.0(18)$ & Male & 13 & Twin, prematurity \\
\hline 2 & $0.0(19)$ & Male & 26 & $\begin{array}{l}\text { Premature rupture of } \\
\text { membranes }\end{array}$ \\
\hline 3 & $0.0(19)$ & Male & 13 & Acute chorioamnionitis \\
\hline 4 & $0.0(19)$ & Male & 6 & Potter syndrome \\
\hline 5 & $0.0(21)$ & Female & 2.5 & Polysplenia \\
\hline 6 & $0.0(21)$ & Female & 14 & Twin, prematurity \\
\hline 7 & $0.0(22)$ & Female & 13.5 & $\begin{array}{l}\text { Twin-to-twin transfu- } \\
\text { sion }\end{array}$ \\
\hline 8 & $0.0(22)$ & Male & 15 & Potter syndrome \\
\hline 9 & $0.0(24)$ & Female & 17.5 & Deciduitis \\
\hline 10 & $0.0(27)$ & Male & 9 & Sepsis \\
\hline 11 & $0.0(30)$ & Male & 12 & $\begin{array}{l}\text { Intrauterine fetal } \\
\text { demise }\end{array}$ \\
\hline 12 & $0.0(32)$ & Male & 17 & Hypoplastic lung \\
\hline 13 & $0.1(28)$ & Male & 17 & $\begin{array}{l}\text { Respiratory distress } \\
\text { syndrome }\end{array}$ \\
\hline 14 & $0.0(35)$ & Female & 14 & $\begin{array}{l}\text { Urorectal septum mal- } \\
\text { formation }\end{array}$ \\
\hline 15 & $0.0(36)$ & Male & 14 & $\begin{array}{l}\text { Intrauterine fetal } \\
\text { demise }\end{array}$ \\
\hline 16 & $0.1(36)$ & Female & 14 & $\begin{array}{l}\text { Protein-loosing gastro- } \\
\text { enteropathy }\end{array}$ \\
\hline 17 & $0.0(43)$ & Female & 22 & Sepsis \\
\hline 18 & 4 & Male & 20 & Aspiration pneumonia \\
\hline 19 & 4 & Male & 14.5 & Severe burn \\
\hline 20 & 4 & & & \\
\hline 21 & 14 & Male & 18 & $\begin{array}{l}\text { Acute lymphocytic } \\
\text { leukemia }\end{array}$ \\
\hline 22 & 21 & Male & 9 & Cystic fibrosis \\
\hline
\end{tabular}

* Age is in years after birth. Numbers in parentheses represent gestational age in wk. a gift from Dr. K. Dierickx $(13,14)$. The two oligonucleotide probes were synthesized locally: human VP-I (HVP-1), a 30-mer oligonucleotide antisense probe complementary to a portion of exon $\mathrm{C}$ of the human VP gene coding for VP-NP with a base sequence of 5'-GGC GCG GCG GTG AAA GAC CTC GCG GCA CTC-3' (2107-2136); and human VP-2 (HVP-2), a 27mer oligonucleotide antisense probe complementary to the glycoprotein coding region in exon $\mathrm{C}$ of the human VP gene with a base sequence of $5^{\prime}$-GGC CCG TCC AGC TGC GTG GCG TTG CTC-3' (2150-2176). Molecular biology grade reagents (Sigma Chemical Co., St. Louis, MO; Bethesda Research Labs, Gaithersburg, MD; Boehringer Mannheim Indianapolis, IN; or Collaborative Research Inc., Bedford, MA) were used whenever possible for ISH.

$I C C$. Deparaffinized, rehydrated $8-\mu \mathrm{m}$-thick paraffin sections or $20-\mu \mathrm{m}$-thick frozen sections were washed for $30 \mathrm{~min}$ in 0.01 M PBS containing $0.1 \%$ Triton X-100, treated with $1 \% \mathrm{H}_{2} \mathrm{O}_{2}$ ( $15 \mathrm{~min}$ ), and washed three times for $5 \mathrm{~min}$ each in $0.01 \mathrm{M}$ PBS followed by $30 \mathrm{~min}$ in 1 to $5 \%$ normal goat serum. The tissue was then incubated overnight in 1:2000 (paraffin sections) or 1:500 (frozen sections) anti-VP-NP II at $4^{\circ} \mathrm{C}$. After three 5-min washes, the antibody was visualized using the avidin biotin complex method (ABC Elite Kit, Vector, Burlingame, CA) and counterstained with methyl green or Giesma. The size of VP-NP II immunoreactive cells was measured on a Leitz Orthoplan microscope coupled to a Bioquant Meg M (R\&M Biometrics, Inc.) image analysis system.

$I S H$. The oligonucleotide probes were labeled to a $\mathrm{sp}$ act of 1 to $3 \times 10^{8} \mathrm{cpm} / \mu \mathrm{g}$ by the addition of $\left[{ }^{125} \mathrm{I}\right]$ deoxycytidine triphosphate to the $3^{\prime}$ end using terminal deoxynucleotide transferase. The labeled probe was then hybridized to frozen or deparaffinized, rehydrated sections using the following protocol.

Deparaffinized, rehydrated paraffin sections were permeabilized two times for 30 min each in $0.01 \mathrm{M}$ PBS ( $\mathrm{pH}$ 7.4) containing $0.3 \%$ Triton $\mathrm{X}-100$ (Sigma) for $1 \mathrm{~h}$ at room temperature followed by incubation for $1 \mathrm{~h}$ at $44^{\circ} \mathrm{C}$ in hybridization buffer (Solution A: $2 \mathrm{~mL} 1 \mathrm{M}$ Tris, pH 8.0; $12 \mathrm{~mL} 20 \times$ SSC: $0.4 \mathrm{~mL}$ $0.5 \mathrm{M}$ EDTA, pH 7.0; $2.4 \mathrm{~mL}$ sterile deionized water; $0.8 \mathrm{~mL}$ $25 \times$ Denhardt's; $1 \mathrm{~g}$ dextran sulfate. Solution B: $0.1 \%$ salmon sperm DNA in $100 \%$ deionized formamide. Five $\mathrm{mL}$ of solution $A$ is boiled, cooled on ice, and mixed with $5 \mathrm{~mL}$ of solution $B$ to form buffer). Slides were drained, and $100 \mu \mathrm{L}$ of freshly prepared hybridization buffer containing 0.5 to $1 \times 10^{6} \mathrm{cpm}$ ${ }^{125}$ I]deoxycytidine triphosphate-labeled oligonucleotide was applied. The sections were covered with coverslips and incubated 30 to $48 \mathrm{~h}$ at $44^{\circ} \mathrm{C}$ in a humidified chamber. Sections were washed at $44^{\circ} \mathrm{C}$ in $4 \times \mathrm{SSC}, 4 \times 30 \mathrm{~min} ; 2 \times \mathrm{SSC}, 2 \times 30 \mathrm{~min}$ : and $0.2 \times$ SSC, $30 \mathrm{~min}$. For double-labeling with ICC and ISH. the ICC staining procedure was begun immediately after the last wash. Finally, slides were dehydrated for $2 \mathrm{~min}$ each in 50,95 . and $100 \%$ ethanol, each containing $0.33 \mathrm{M}$ ammonium acetate followed by pure $100 \%$ ethanol.

After drying approximately $2 \mathrm{~h}$, slides were dipped in NTB-2 (Kodak, Rochester, NY) nuclear track emulsion at $42^{\circ} \mathrm{C}$ diluted 1:1 with distilled water. Slides were exposed $2 \mathrm{wk}$ and then developed in D-19, washed, and fixed. Sections were counterstained with Giemsa or methyl green, dehydrated in a graded ethanol series, cleared in xylene, and coverslipped with Permount.

The specificity of the hybridization to VP mRNA was assessed by comparing hybridization of the VP probe in vasopressinergic magnocellular neurons with: 1 ) hybridization to the VP probe to cells of comparable size in adjacent regions, and 2) hybridization of a randomer probe or a probe to a non-CNS peptide to the VP magnocellular neurons. In addition, histologic sections that were predigested by RNAse A $(40 \mu \mathrm{g} / \mathrm{mL}$. Sigma) for 30 min before hybridization or sections that were prehybridized with a 50-fold excess of unlabeled probe showed no specific labeling above background (not shown).

Data analysis. Silver grain densities over individual VP neu- 


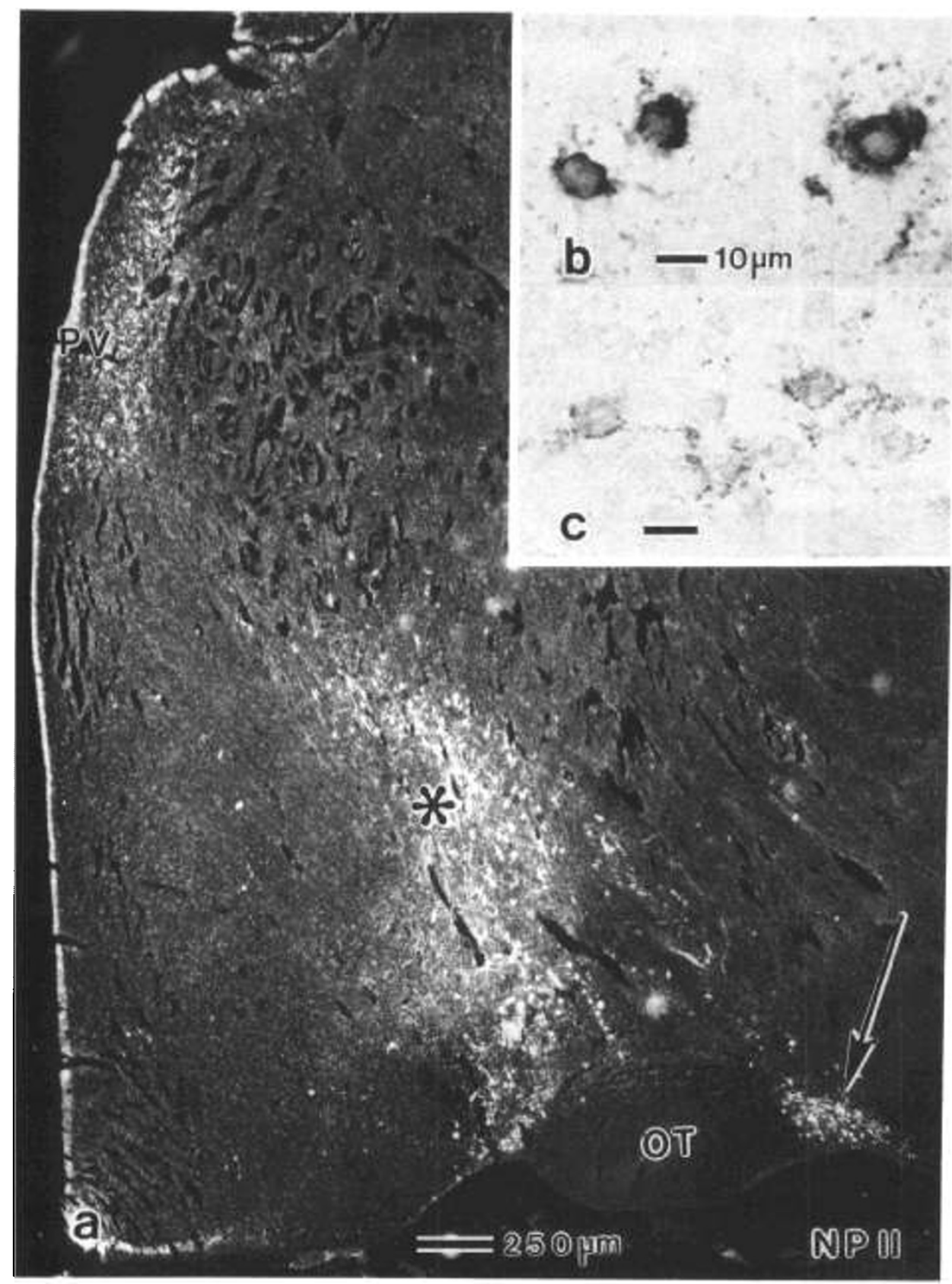

Fig. 1. VP-NP II ICC in the hypothalamus of an 18-wk-old fetus. $a$, dark field photomicrograph showing the distribution of immunoreactive cells in paraventricular ( $P V$ ), supraoptic (large arrow), and $\mathrm{SON}-a c c\left({ }^{*}\right) ; b$, high magnification of strongly stained neurons in the paraventricular nucleus: and c, lightly stained neurons in the SON. OT, optic tract.

rons in the SON, SON-acc, and PVN were evaluated at a magnification of $375 \times$ under reflected polarized light with a Bioquant Meg $M$ image analysis system. In addition, the brightened image was used in conjunction with the reflected polarized light to visualize the Giemsa or immunocytochemically stained cells for measurement of cell area. Using these two measurements for each cell, the mean number of silver grains $/ \mu \mathrm{m}^{2}$ was automatically calculated for each cell, and the mean silver grain density per cell was calculated for each brain. Measurements of cells from the hypothalamus of several cases within each age range were pooled to provide the most representative sample possible.

\section{RESULTS}

Histologic sections from various regions of the CNS processed for routine neuropathology were unremarkable except for case 5 , which showed a small amount of intraventricular hemorrhage.
Immunoreactive VP-NP II was detected in all 22 specimens included in this study, although at $18 \mathrm{WG}$, staining was often weak. At $18 \mathrm{WG}$, the magnocellular nuclei were already well formed with an adult-like pattern (Fig. $1 a$ ) except for the relatively large size of SON-acc, although at this stage magnocellular neurons were difficult to identify reliably on Nissl-stained sections because of the immature shape of each cell (Fig. $1 b$ and $c$ ). The most strongly stained VP cells (Fig. $1 b$ ) were found in the SON-acc and PVN. In the SON, most cells were stained more lightly (Fig. 1 c). This difference was consistently observed in all the cases examined, although the difference was less obvious in specimens from older patients. The intensity of immunoreactivity in the neuroendocrine cells increased rapidly with development (not illustrated). In addition, the size of VP-NP immunoreactive cells continued to increase slowly with development (Fig. 2).

ISH. VP mRNA was detectable in all cases from 21 WG (Fig. 3 ) to $21 \mathrm{y}$ of age. As illustrated in Figure 4, the average cellular 


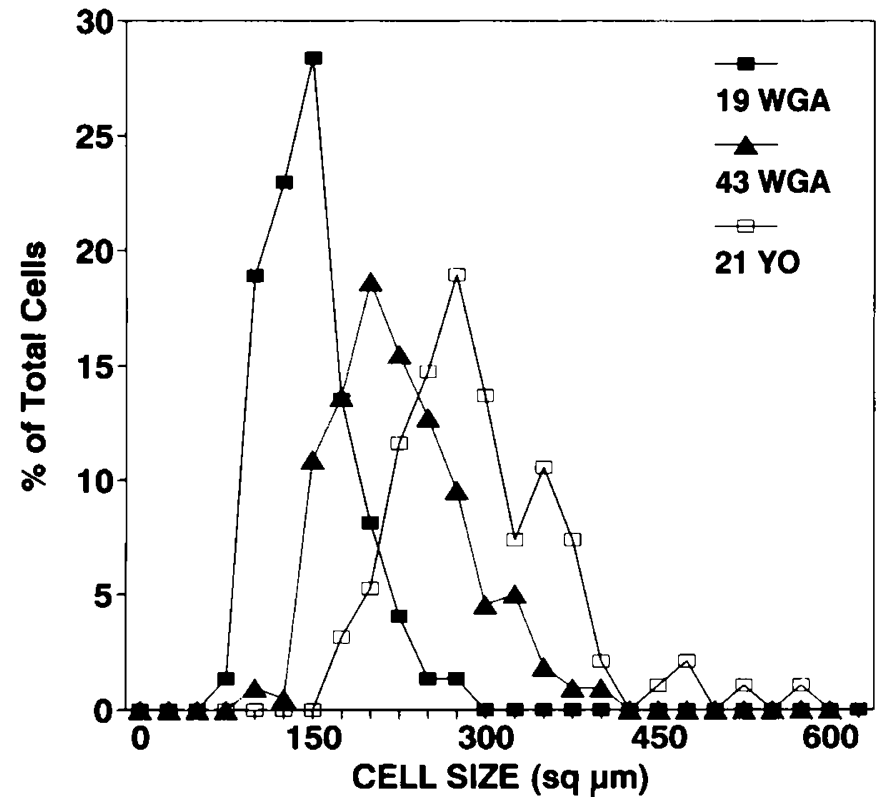

Fig. 2. Development of cell size in the paraventricular nucleus. The frequency distributions of cell sizes for immunocytochemically identified cells are compared for a 19-wk-old fetus, term baby, and 21 -yr-old adult. A shift to the right in the curves reflects an increase in the cell areas.

hybridization signal (grains $/ \mu \mathrm{m}^{2}$ ) stabilized at a constant value after $30 \mathrm{WG}$ and was easy to detect. At younger ages ( $\leq 21 \mathrm{WG})$. fetal brains showed consistently high background (e.g. Fig. 4 , control) and we were unable to detect reliable specific hybridization with our method. The brain from a fetus less than $21 \mathrm{WG}$ is usually soft and edematous due to greater interstitial fluid.
This increased interstitial fluid could contribute to the high ISH background. We have used the HVP-1 and the HVP-2 probes alone and together to improve sensitivity but could not identify neurons with VP-mRNA labeling above the high background labeling encountered in fetal brain less than $21 \mathrm{WG}$. At $21 \mathrm{WG}$, specific hybridization was first detectable but was low relative to older fetuses. Labeling of the suprachiasmatic nucleus and other brain regions with low VP mRNA abundance was observed in older fetuses, further confirming the sensitivity of the oligonucleotide probes used in these studies. Postmortem periods of 9 to $22 \mathrm{~h}$ before fixation had no detectable effect on the hybridization signal intensity. In addition, similar results were obtained from frozen sections and sections from paraffin blocks of autopsy files kept for more than $1 \mathrm{y}$.

Double-labeling with ICC and ISIH. Neurons positive for both ICC and ISH were detectable from $27 \mathrm{WG}$. However, the intensity of the ICC that was obtained with double-labeling at this age was weaker than with ICC alone. In specimens from the fullterm infant. double-labeling provided intense signals comparable to ISH or ICC alone (Fig. 5).

With the double-labeling method, three single-cell staining patterns were present: type 1 , intensely positive for both ISH and ICC: type 2, positive for ISH and weak or negative for ICC; and type 3, positive for ICC and weak or negative for ISH. At young ages, the ventrolateral SON consistently showed the second staining pattern. The third pattern was seen in the majority of neurons of the SON-acc and a few neurons of the PVN and the dorsomedial SON. A comparison of the frequency distribution of single-cell silver grain densities from the SON to that of the PVN in the mature hypothalamus (14 y) is illustrated in Figure 6. The density of labeling was almost identical in VP cells found in both regions, indicating similar VP mRNA production in the adult SON and PVN.
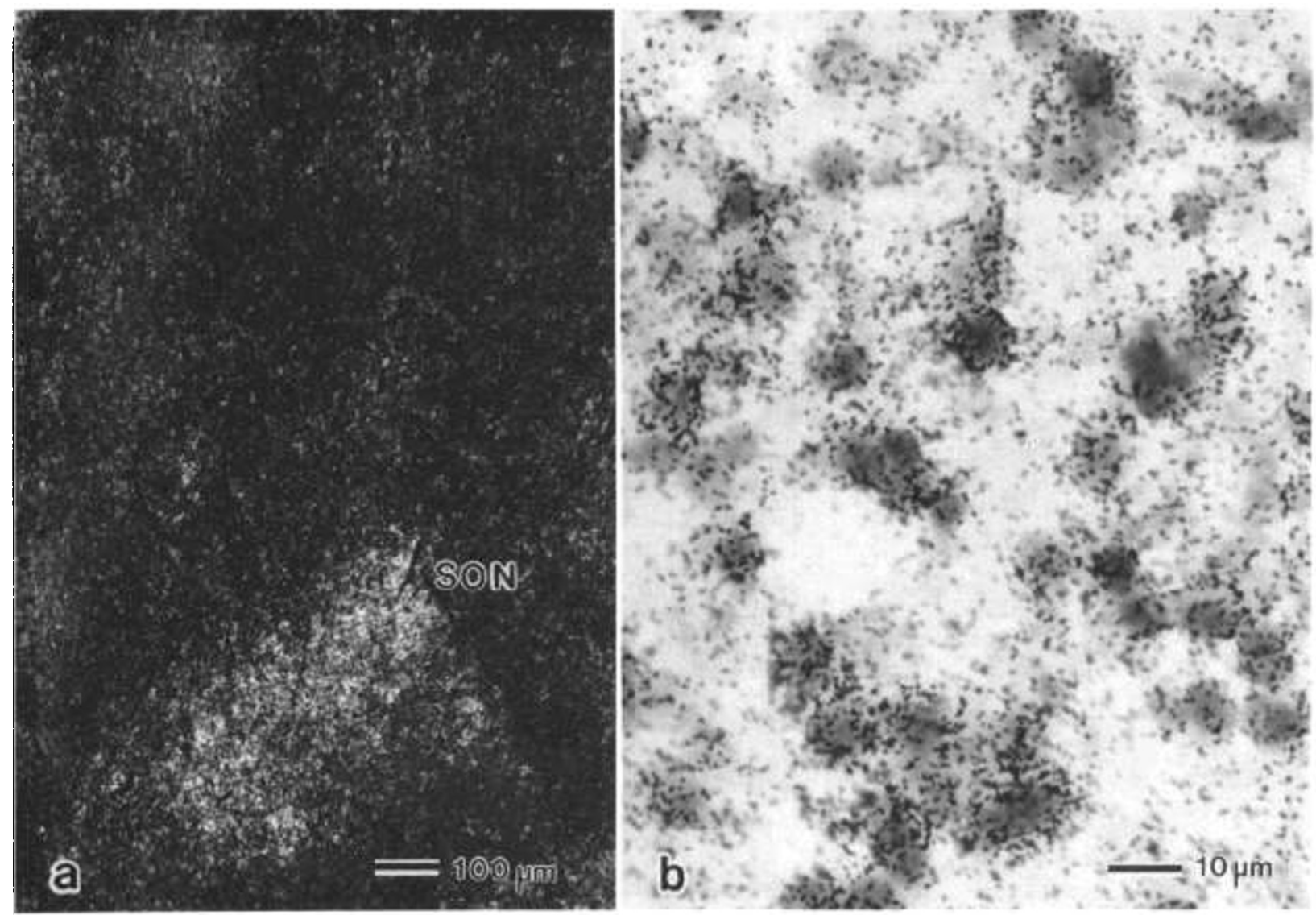

Fig. 3. ISH histochemistry for VP mRNA in a 21-wk-old fetus. $a$. Dark field image at low magnification showing diffuse labeling in the SON: $h$. bright field photomicrograph at high magnification illustrating the localization of silver grains over immature cells in the SON. 


\section{DEVELOPMENT OF VP mRNA}

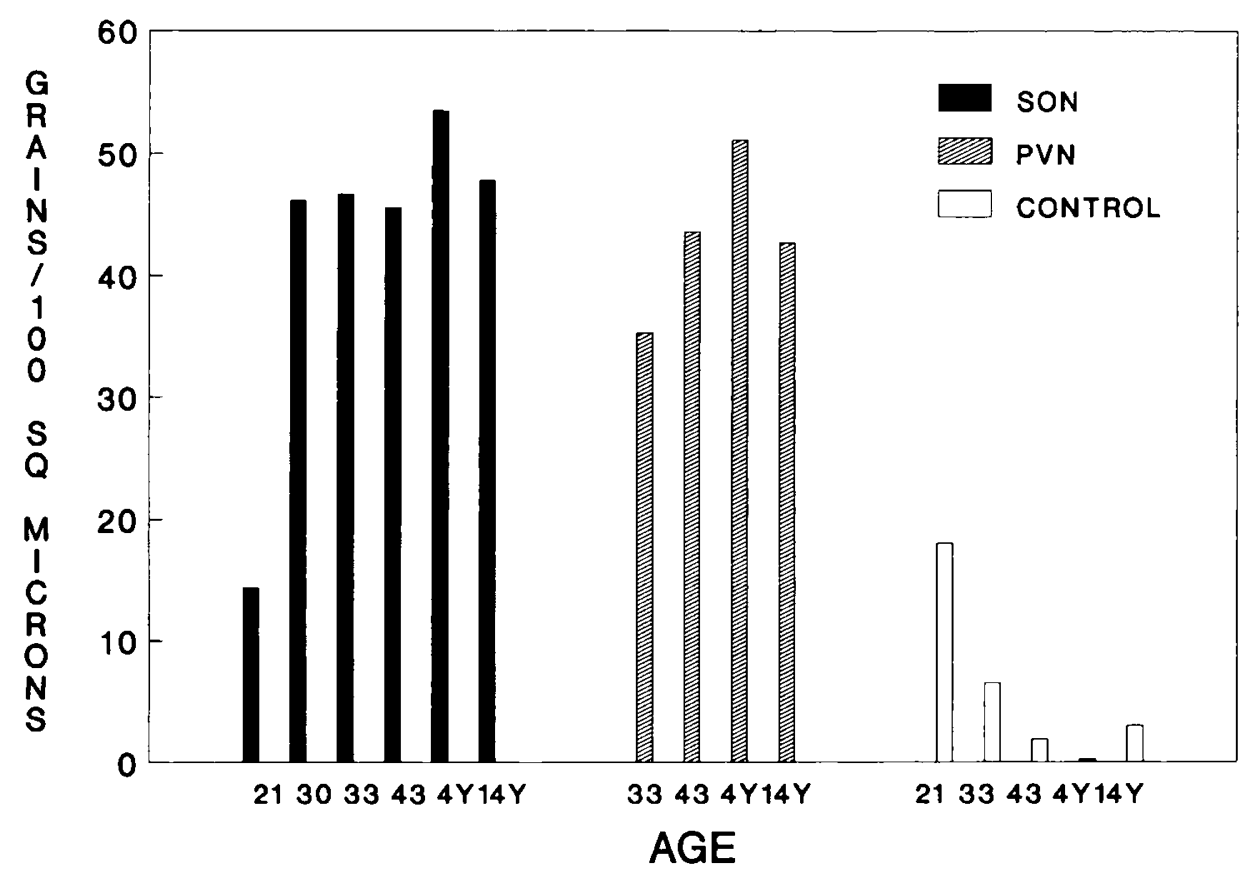

Fig. 4. Average specific single-cell silver grain densities resulting from the hybridization of the HVP-1 probe to VP $m$ RNA in cells from the SON or PVN at different ages. Large non-VP cells were also sampled as controls and illustrate total nonspecific silver grain densities, which were subtracted to give silver grain densities specific for VP mRNA. Hybridization of the probe is equivalent in the SON and PVN at all ages except in the 21 -wkold fetus, which had a higher background and a much lower level of labeling.

\section{DISCUSSION}

The measurement of mRNA content in individual cells by ISH histochemistry provides a powerful tool for the assessment of gene expression in human fetal and adult autopsy material. In combination with ICC, both peptide and message levels can be evaluated in the same cell to given an indication of the peptide content and peptide synthesis in the cells at the time of death. The present study demonstrates the applicability of simultaneous double-labeling by ICC and ISH for VP and VP mRNA in routine paraffin blocks of human fetal and adult hypothalamus.

The presence of immunoreactive VP in the human fetal hypothalamus and within terminal endings in the neural lobe of the pituitary has been described as early as 8.5-11 WG $(9,15)$. The presence of VP peptide early in development indicates that VP mRNA is transcribed and translated well before the establishment of functional synaptic interactions. The significance of this early appearance is not known, although it has been suggested that VP may have an early trophic function (6). The content of VP increases rapidly between 10 and 24 WG $(9,10)$ correlating in time with the first appearance of neurosecretory endings in the neural lobe at 10 to 11 WG (15).

In the rat, where the development of the magnocellular neuroendocrine system has been investigated more thoroughly, the appearance of VP at E16 (1-5) (approximately 1-2 d after migration is complete) is followed sequentially by a gradual innervation of the neural lobe starting at E18-19 $(2,5)$, the appearance of catecholaminergic synapses at E21-birth $(4,10)$, the ability to respond to osmotic stimuli at E19-PN1 $(7,16)$, full water balance regulation by PN14-18 (17), and the appearance of adult-like cellular characteristics by PN14-21 $(3,5)$. If development of the human VP neuroendocrine system follows a similar pattern, the development of organelles and related biochemistry for VP mRNA transcription and translation would be followed by development of terminal endings for secretion of VP and establishment of synaptic innervation of the VP cells. Before 21 WG, small amounts of VP are detectable by ICC, although
VP mRNA is below the detection threshold. Between 21 and 28 WG, both steady state VP content and VP mRNA levels begin to rise until, after $27 \mathrm{WG}$, both VP and VP mRNA were plentiful in the magnocellular neurons. These changes are accompanied by an increase in cell size, suggesting that the cells are still maturing functionally during this period. Although our results could be interpreted as indicating an absence of brain VP mRNA. before $21 \mathrm{WG}$, the presence of VP by ICC indicates that some VP mRNA translation has occurred. The low values for specific hybridization early in development can be attributed to some extent to the higher level of background in tissue from the young fetus. More sensitive methods for detection might detect significant, albeit very low, levels of VP mRNA. The use of multiple simultaneous oligonucleotide probes in our studies, however, did not improve our detection of VP mRNA in fetal brain from the fetus younger than 21 WG. In these studies, we have not used RNA probes, another technique that may improve ISH sensitivity. Another possible explanation for undetectable VP mRNA is that VP mRNA may be less stable postmortem in the young fetuses. However, our present data on postmortem intervals do not support the possibility that VP mRNA is less stable postmortem in the young fetus. Furthermore, Arai et al. (18) have shown only minimal loss of VP ISH labeling in rat hypothalamic nuclei of rat brain left at room temperature for $8 \mathrm{~h}$ before fixation. Thus, the late development of detectable VP mRNA suggests that steady state levels of message are very low early in development and may not increase until the appearance of functional synaptic mechanisms for release of VP. Even in adult tissue, a proportion of the VP neuroendocrine cells do not express significant mRNA until conditions are presented that stimulate VP secretion (8). A previous study of human postmortem brain has shown that adult postmortem brain does show neuronal VP mRNA hybridization densities that correlate with antemortem hydration (1).

The identification of three populations of VP neurons after 27 WG underscores the importance of both ISH and ICC for 

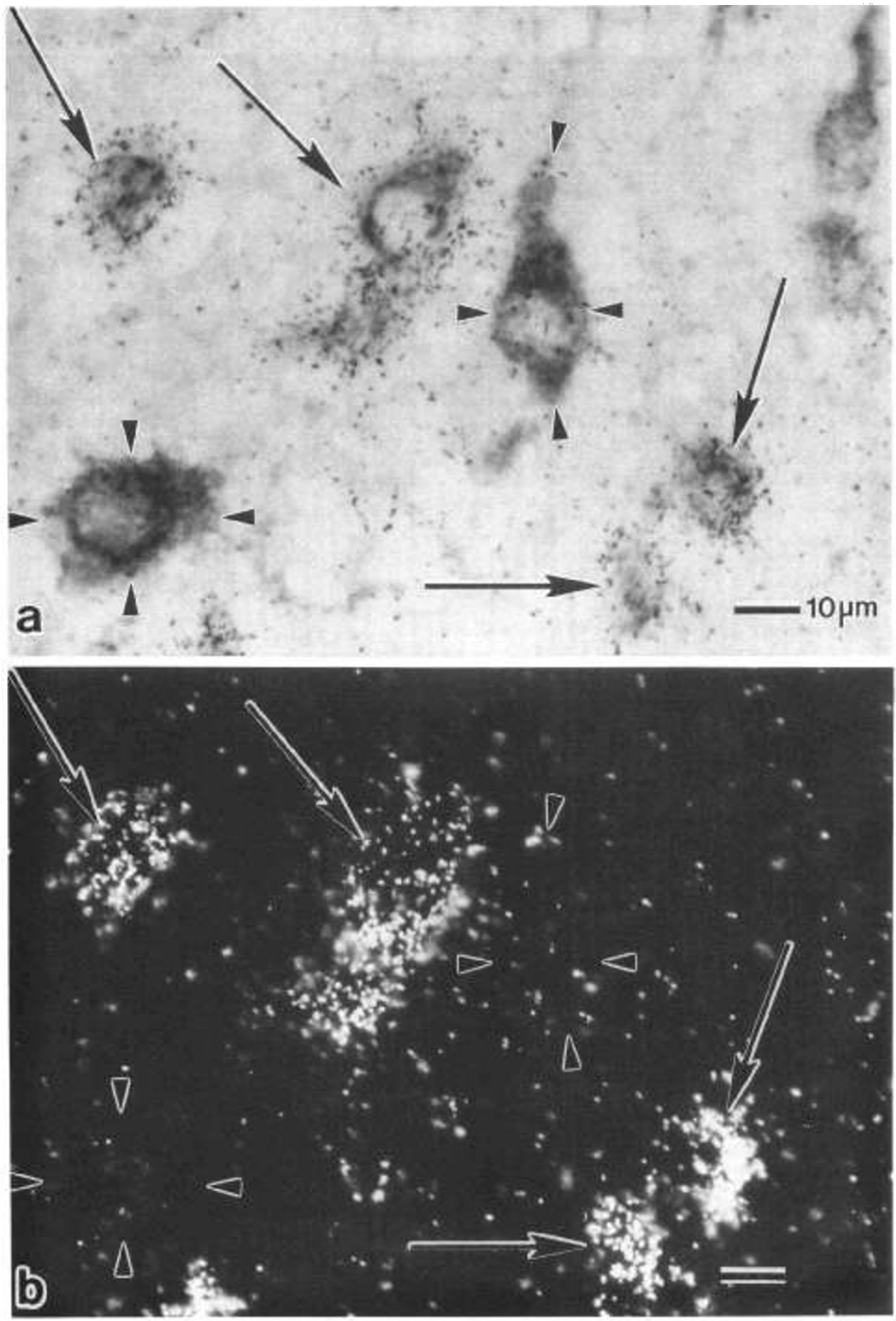

Fig. 5. Double-labeling for VP and VP mRNA in single cells from the brain of a 14-yr-old individual. Bright field $(a)$ and dark field $(b)$ images show silver grains on cells immunoreactive for VP-NP II. Double-labeled cells (arrows) and strongly immunoreactive cells with no detectable VP mRNA (arrowheads) are present in the same section.

analysis of the cells. Most cells are strongly positive for both VP and VP mRNA and do not differ significantly from cells sampled from the mature CNS. However, at all ages, we observed some cells that contained immunoreactive VP but no VP mRNA. Other studies of brain peptides in human autopsy material also have reported neurons or regions of the brain that either had weak ISH labeling but prominent immunoreactivity or the converse $(19,20)$. Such observations may indicate that mRNA production is a dynamic process that normally may fluctuate between low and high levels in the same cell. This conclusion is consistent with our observations in normal rat SON (8) as well as in the ISH study using human autopsy material reported by Rance and Young (21). In that study, they compared ISH of substance $\mathrm{P}$ and neurokinin $\mathrm{B}$ in the same neuronal populations of brain sections from premenopausal and postmenopausal women. The authors found that the most prominent change in the hypothalamus of the brains of postmenopausal women was an increased "density" of neurons labeled for the substance P and neurokinin B. These authors, then, noted more neurons labeled by ISH in the postmenopausal women than in premenopausal women, possibly by "recruitment" of additional neurons (21). This finding is quite similar to the increased number of ISH-labeled neurons we have found in the PVN of the brain from dehydrated rats when compared with the PVN from hydrated rats (8).

Our studies and the study of Rivkees et al. (1) demonstrate 


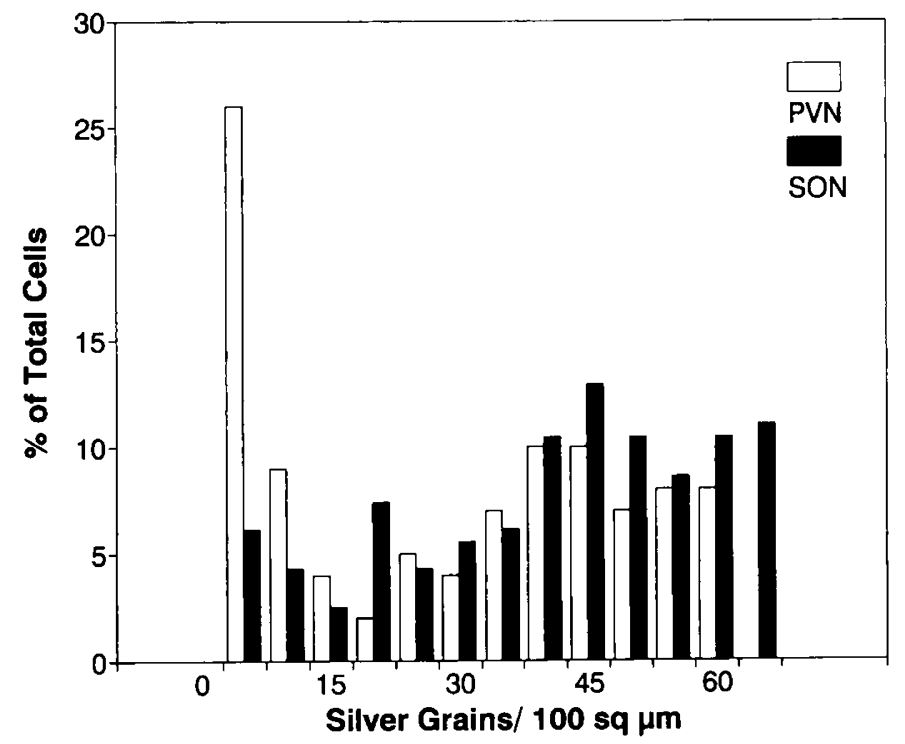

Fig. 6. Frequency distribution of single-cell silver grain densities within immunocytochemically identified cells in the SON and PVN of a 14-yr-old. A wide range of silver grain densities was found, with similar distributions in the SON and PVN. Many more cells in the PVN were observed with low, nonspecific labeling (0-15 silver grains/100 sq $\mu \mathrm{m})$ indicating a greater number of immunoreactive cells in the PVN that do not express significant VP mRNA.

that combined ISH and ICC can be applied to paraffin or frozen sections of human fetal autopsy material. Furthermore, we have found that, although VP synthesis is established at very early ages, VP mRNA is not expressed at high levels until after 21 WG. By 27 to 30 WG, most VP neurons express adult-like levels of both VP and VP mRNA. These observations suggest a correlation of VP mRNA production with the development of synaptic mechanisms for control of VP secretion. The analysis of both peptide and message levels in fetal and adult human autopsy material provides a valuable tool for the investigation of gene expression in association with pathologic or nonpathologic conditions.

\section{REFERENCES}

1. Rivkees SA, Chaar MR, Hanley DF, Maxwell M, Reppert SM, Uhl GR 1989 Localization and regulation of vasopressin mRNA in human neurons. Synapse 3:246-254

2. Buijs RM, Velis DN, Swaab DF 1990 Ontogeny of vasopressin and oxytocin in the fetal rat: early vasopressinergic innervation of the fetal brain. Peptides $1: 315-324$

3. Khachaturian H, Sladek Jr JR 1980 Simultaneous monoamine histofluorescence and neuropeptide immunocytochemistry: III. Ontogeny of catecholamine varicosities and neurophysin neurons in the rat supraoptic and paraventricular nuclei. Peptides 1:77-95

4. Silverman AJ, Goldstein R. Gadde CA 1980 The ontogenesis of neurophysincontaining neurons in the mouse hypothalamus. Peptides 1(Suppl):27-44

5. Sinding C, Czernichow P, Seif SM, Robinson AG 1980 Quantitative changes in neurohypophyseal peptides in the developing brain. Peptides !(suppl):4550

6. Altstein M, Gainer H 1988 differential biosynthesis and posttranslational processing of vasopressin and oxytocin in rat brain during embryonic and postnatal development. Neuroscience 8:3967-3977

7. Sladek CD, Gash DM. Khachaturian H. Scott DE. Sladek Jr JR 1980 Maturation of the supraoptic nucleus: a multidisciplinary analysis. Peptides 1(suppl):51-67

8. Meeker RB, Greenwood RS, Hayward JN 1991 Vasopressin mRNA expression in individual magnocellular neuroendocrine cells of the supraoptic and paraventricular nucleus in response to water deprivation. Neuroendocrinology $54: 236-247$

9. Fellmann K, Bloch B, Bugnon C, Lenys D 1979 Etude immunocytologie de la maturation des axes neuroglandulaires hypothalamo-neurohypophysaires chez le foetus humain. J Physiol (Paris) 75:37-43

10. Burford GD, Robinson ICF 1982 Oxytocin, vasopressin and neurophysins in the hypothalamo-neurohypophysial system of the human fetus. J Endocrino 95:403-408

11. Goudsmit E, Hofman MA. Fliers E, Swaab DF 1990 The supraoptic and paraventricular nuclei of the human hypothalamus in relation to sex, age and Alzheimer's disease. Neurobiol Aging 11:529-536

12. Morton A 1969 A quantitative analysis of the normal neuron population of the hypothalamic magnocellular nuclei in man and of their projections to the neurohypophysis. J Comp Neurol 136:143-158

13. Diedrickx K. Vandesande F 1977 Immunocytochemical localization of the vasopressinergic and oxytocinergic neurons in the human hypothalamus. Cell Tissue Res 184:15-27

14. Diedrickx Y, Vandesande F 1979 Immunocytochemical demonstration of separate vasopressin-neurophysin neurons in the human hypothalamus. Cell Tissue Res 196:203-212

15. Okado N, Yokata N 1980 An electron microscopic study on the structural development of the neural lobe in the human fetus. Am J Anat 159:261273

16. Reppert SM, Uhl GR 1988 The vasopressin gene is expressed prior to regulation in the supraoptic nuclei of fetal rats. Brain Res 456:392-396

17. Dlouha H, Krecek J. Zicha J 1982 Postnatal development and diabetes insipidus in Brattleboro rats. Ann NY Acad Sci 394:10-19

18. Arai H, Noguchi I, Sagi N, Moroji T, lizuka R 1989 A study of non-isotopic in situ hybridization histochemistry on postmortem changes in vasopressin mRNA in rat brain. Neurosci Lett 103:127-132

19. Chan-Palay V 1988 Techniques for the simultaneous demonstrations of neuropeptide $Y$ gene expression and peptide storage in single neurons of the human brain. Histochemistry 90:123-127

20. Brene S, Lindefors N, Kopp J, Sedvall G, Persson H 1989 Regional distribution of neuropeptide $\mathrm{Y}$ mRNA in postmortem human brain. Molec Brain Res $6: 241-249$

21. Rance N, Young III WS 1991 Hypertrophy and increased gene expression of neurons containing neurokinin-B and substance- $P$ messenger ribonucleic acids in the hypothalami of postmenopausal women. Endocrinology 128:2239-2247 